\title{
RANCANG BANGUN SISTEM INFORMASI PRAKTEK KERJA LAPANGAN TERINTEGRASI MENGGUNAKAN WEBSERVICE
}

\author{
Teguh Andriyanto \\ Fakultas Teknik, Program Studi Sistem Informasi \\ Universitas Nusantara PGRI Kediri \\ Email: teguh@unpkediri.ac.id \\ Risky Aswi R \\ Fakultas Teknik, Program Studi Teknik Informatika \\ Universitas Nusantara PGRI Kediri \\ Email: risky_aswi@unpkediri.ac.id
}

\begin{abstract}
ABSTRAK
Universitas Nusantara PGRI Kediri (UN PGRI Kediri) merupakan salah satu perguruan tinggi yang ada di Kota Kediri memiliki beberapa fakultas salah satunya yaitu Fakultas Teknik. Dalam kurikulum Prodi Sistem Informasi, yang berada dibawah Fakultas Teknik, terdapat mata kuliah Praktek Kerja Lapangan (PKL) yang dilaksanaman pada semester VII. Proses pendaftaran dan pelaporan PKL saat ini masih dilakukan secara manual yang menimbulkan kendala bagi Ketua Prodi Sistem Informasi untuk melakukan pemilihan/penugasan dosen pendamping PKL dan monitoring proses PKL serta lambatnya proses pembualan laporan hasil PKL oleh bagian administrasi Prodi. Untuk mengatasi permasalahan tersebut dalam penelitian ini dirancang dan dibangun Sistem Informasi Praktek Kerja Lapangan (SIM PKL) yang terintegrasi dengan data Sistem Informasi Akademik UN PGRI Kediri menggunakan RESTFul Webservice. Hasil penelitian ini adalah software aplikasi Sistem Informasi Praktek Kerja Lapangan (SIM PKL) berbasis web menggunakan bahasa pemrograman php dan databse MySql.
\end{abstract}

Kata kunci: praktek kerja lapangan, RESTFul webservice.

\section{ABSTRACT}

University Nusantara PGRI Kediri (UN PGRI Kediri) is one of the colleges in the city of Kediri has several faculties one of which is the Faculty of Engineering. in the curriculum of Information Systems Department, which is under the Faculty of Engineering, there are courses Job Training (PKL) are implemented on the semester VII. The registration process and PKL reporting is still done manually which pose obstacles for Chair of Information Systems Department to make the selection / assignment the $P K L$ supervisor and monitoring process as well as the slow process of PKL reporting. To overcome these problems in the study was designed and constructed Job Training Information System (SIM PKL) that integrated with Academic Information System UN PGRI Kediri using the RESTful Webservice. The result of this research is a web-based application software of Information Systems Job Training using programming languages PHP and MySql database.

Keywords: job training, RESTFul webservice.

\section{PENDAHULUAN}

Universitas Nusantara PGRI Kediri (UN PGRI Kediri) merupakan salah satu perguruan tinggi yang ada di Kota Kediri memiliki beberapa fakultas salah satunya yaitu Fakultas Teknik. Dalam kurikulum Prodi Sistem Informasi, yang berada dibawah Fakultas Teknik, terdapat mata kuliah Praktek Kerja Lapangan (PKL) yang dilaksanaman pada semester VII [1]. Dalam PKL, mahasiswa diharapkan dapat mengasah mental dan pengetahuan dalam mengenal dunia kerja sebelum memasuki dunia kerja setelah lulus. Disamping itu mahasiswa juga diharapkan mampu menerapkan ilmu pengetahuan yang didapat selama kuliah untuk menganalisa dan memperbaiki sistem yang ada di tempat PKL. Sehingga mahasiswa dapat memberikan sumbangsih guna memperbaiki proses bisnis maupun layanan dalam pada perusahaan tempat PKL pada khususnya dan masyarakat pada umumnya. PKL dilaksanakan secara kelompok dengan jumlah anggota maksimal 5 orang. Jangka waktu pelaksanaan rata-rata adalah 30 hari. Untuk membantu kelancaran PKL maka setiap kelompok akan didampingi oleh seorang dosen pendamping yang ditunjuk oleh prodi. Dosen pendamping ini juga bertanggung jawab untuk memberikan penilaian terhadap hasil PKL. 
Saat ini proses pendaftaran dan pelaporan pelaksanaan PKL di Prodi Sistem Informasi masih dilakukan secara manual. Proses manual inilah yang menjadi kendala bagi Ketua Prodi Sistem Informasi untuk melakukan pemilihan/penugasan dosen pendamping PKL serta monitoring proses PKL. Disamping itu proses manual juga menjadi kendala lambatnya proses pembuatan laporan hasil PKL oleh bagian administrasi Prodi. Bagian administrasi prodi juga seringkali tidak dapat melakkan pendataan secara lengkap dikarenakan dokumen fisik persyaran PKL terselip atau hilang. Mahasiswa juga harus selalu menanyakan ke prodi mengenai data dosen yang akan membimbing PKL kelompok mereka.

Penggunaan Sistem Informasi PKL merupakan solusi dalam mengatasi permasalahan tersebut diatas. Proses pendaftaran sampai dengan penilaian PKL dapat dilakukan secara efektif dan efisien sehingga mempermudah dalam monitoring pelaksanaan PKL. Sistem Informasi PKL yang digunakan harus mampu berintegrasi dengan data dasar universitas yaitu mahasiswa dan dosen yang saat ini dikelola oleh Biro Sistem Informasi. Proses integrasi data dapat dilakukan dengan berbagai macam cara. Dalam penelitian ini, proses integrasi data menggunakan web service.

Penelitian mengenai Sistem Informasi Manajemen Praktek Kerja Lapangan telah banyak dilakukan dengan berbagai studi kasus. Arifin [2] telah melakukan analisa dan perancangan praktek kerja lapangan pada instansi/perusahaan. Analisa dan merancang meliputi pendaftaran, jadwal, kuota peserta PKL, antrian serta penilaian PKL. Dengan analisa dan perancangan tersebut diharapkan tempat PKL dapat membangun dan menerapkan pada instansi/perusaannya masing-masing sehingga pelaksanaan PKL dapat berjalan dengan baik dan semua pihak mendapatkan manfaat dari kegiatan PKL. Hasil dari penelitian tersebut adalah rancangan tabel database.

Penelitian mengenai PKL juga telah dilakukan oleh Adiwinata [3] dengan menggunakan metode Unified Process yang merupakan salah satu metode pengembangan perangkat lunak yang menerapkan konsep berorientasi obyek. Sistem informasi PKL tersebut mengambil studi kasus pada PKL yang ada pada program studi Teknik Informatika Universitas Diponegoro. Perancangan sistem informasi tersebut menggunakan Unified Modelling Language. Hasil penelitian tersebut adalah aplikasi Sistem Informasi Tugas Akhir dan Praktek Kerja Lapangan yang dibangun menggunakan web server Apache 2.2.11, DBMSMySQL versi 5.0.51a, dan bahasa pemrograman PHP versi 5.2.8.

Penelitian serupa juga telah dilakukan oleh Chandra.K [4] yang merancang dan mengimplementasikan sistem informasi manajemen praktek kerja lapangan berbasis web menggunakan YUI library. Penelitian tersebut mengambil studi kasus di PT. PLN (persero) P3B Jawa Bali APP Salatiga. Hasil penelitian tersebut adalah aplikasi sistem informasi manajemen PKL yang dibangun dengan menggunakan Yahoo User Interface (YUI) sebagai front end programming dan PHP sebagai back end programming. Fitur-fitur yang ada dalam aplikasi tersebut adalah surat balasan, berita/pengumuman, pembuatan id card mahasiswa PKL serta absensi mahasiswa.

Penelitian mengenai web service telah dilakukan oleh Santoso yaitu dengan membuat perangkat lunak untuk mengintegrasikan data dari beberapa situs penjualan (Amazon, Commision Junction, dan Ebay) [5]. Perangkat lunak tersebut menangani penambahan, perubahan dan penghaspusan data produk yang tersimpan dalam database. Sementara itu Penelitian serupa juga dilakukan oleh Hidayat yang menerapkan teknologi web service untuk mengintegrasikan layanan puskesmas dan rumah sakit [6]. Sistem dibangun berbasis web. Aplikasi untuk rumah sakit menggunakan ASP.NET sedangkan pada Asri Medical Center (AMC) menggunakan PHP. Sehingga web service provider pada rumah sakit dan AMC dibangun sesuai dengan bahasa pemrograman masing-masing. Hasil integrasi berupa sebuah sistem yang merupakan hasil gabungan data dari dua rumah sakit tersebut. Sistem yang dibangun memanfaatkan SMS pemberitahuan dari bank yang diterima oleh server SMS Gateway. Data SMS tersebut selanjutnya diproses untuk mengupdate status pembayaran mahasiswa. Semetara web service digunakan untuk menampilkan daftar mahasiswa yang sudah membayar dan yang belum membayar spp. Web service tersebut dibangun menggunakan PHP Framework Codeigniter dan data yang diolah berformat JSON.

Sementara itu melalui makalah penelitiannya, Sutanta mengungkapkan kondisi sistem informasi yang ada di pemkab Bantul DIY [7]. Pemkab Bantul telah mengembangkan 33 aplikasi sistem informasi yang sebagian besar dapat diakses dari portal web pemkab Bantul. Akan tetapi aplikasi-aplikasi tersebut belum terintegrasi. Sedangkan Sutanta melihat adanya kesamaan obyek data (entitas) dan kedekatan hubungan antar obyek data yang diolah dalam sistem informasi. Sehingga perlu dirancang layanan web service antar aplikasi e-Gov pemkab Bantul dengan menggunakan model REST.

Pada penelitian ini akan dirancang dan dibangun sistem informasi manajemen praktek kerja lapangan menggunakan RESTFul web service. Web service digunakan untuk mengambil data dasar universitas yang berada dalam server pusat Universitas Nusantara PGRI Kediri yaitu data login, mahasiswa dan dosen. Aplikasi dibangun menggunakan PHP sebagai backend programming dan database MySQL.

\subsection{Praktek Kerja Lapangan}

Dalam dunia industri sering dijumpai seorang lulusan baru sebuah Perguruan Tinggi yang mengalami kesulitan dalam menghadapi kenyataan di lapangan kerja. Hal ini disebabkan kurang siapnya 
lulusan tersebut dalam menghadapi kondisi kerja di lapangan yang belum pernah mereka alami sebelumnya dan semua dianggap hal baru dan berbeda dengan yang didapat di bangku kuliah. Untuk menghadapi masalah tersebut maka setiap mahasiswa Universitas Nusantara PGRI Kediri, khususnya Program Studi Sistem Informasi diwajibkan untuk melaksanakan Praktek Kerja Lapangan (PKL).

Dalam kegiatan ini mahasiswa dihadapkan pada kerja nyata yang harus disesuaikan dengan pengetahuan dan keterampilan yang dikuasainya dan diharapkan dapat bekerja dengan terampil, disiplin, kreatif, dan jujur sesuai dengan pekerjaan yang dihadapinya. Dengan adanya Praktek Kerja Lapangan (PKL) maka diharapkan akan ada 6 tolak ukur kesesuaian antara Universitas Nusantara PGRI Kediri sebagai sumber daya tenaga kerja dengan perusahaan atau instansi lain yang menjadi pasar tenaga kerja. Menimbang hal tersebut di atas serta berdasarkan persyaratan yang diberikan Program Studi Sistem Informasi mengenai pemilihan objek PKL, yaitu agar objek PKL yang dipilih memiliki keterkaitan dengan ilmu yang diperoleh di bangku kuliah.

Peningkatan ilmu pengetahuan dan teknologi dalam dunia kerja menuntut perusahaan/instansi untuk meningkatkan kualitas di segala bidang. Selain itu peran pemerintah yang turut mendorong pertumbuhan dan keberhasilan perusahaan/instansi dengan mengeluarkan peraturan dan kebijakan bagi perusahaan/instansi di Indonesia. Permasalahan dalam bidang teknik yang kompleks dan sangat menarik sangat penting bagi kami untuk mengenal dan mendalaminya lebih jauh. Adapun tujuan dari kegiatan Praktek Kerja Lapangan ini adalah:

a) Menerapkan teori dan keterampilan praktis yang diperoleh dari bangku kuliah pada perusahaan/instansi yang sebenarnya.

b) Membandingkan teori dengan praktek apakah teori yang diperoleh telah sesuai dengan penerapan dan mengetahui apakah mata kuliah yang diberikan telah sesuai dengan kebutuhan perusahaan/instansi.

c) Untuk menambah wawasan, dengan PKL mahasiswa akan mendapatkan gambaran kerja yang sesungguhnya dan memungkinkan pula mendapatkan pengalaman yang selama ini belum pernah dialami.

\subsection{RESTFul Webservice}

REST didasari oleh empat prinsip utama teknologi [8], yaitu:

a) Resource identifier through Uniform Resource Identifier (URI)

b) Uniform interface (sumberdaya CRUD menggunakan operasi PUT, GET, POST, dan DELETE)

c) Self-descriptive messages (sumberdaya tidak terikat sehingga dapat mengakses konten HTML, XML, PDF, JPEG, plain text, meta data, dll) d). Stateful interactions through hyperlinks (bersifat stateless).

REST memiliki keuntungan yaitu [9]:

a) Support komunikasi stateless

b) Mudah unutk dipelajari dan diterapkan

c) Penggunaan HTTP secara efeisien

d) Membutuhkan bandwidth yang kecil pada saat mengirim pesan dalam format JSON (Javascript Object Notation) dan juga dapat digunakan format lain

e) Untuk keamanan menggunakan standart HTTP

f) REST dapat dikonsumsi oleh beberapa client.

g) REST membuat data sebagai sumber daya.

Sedangkan kelemahan REST adalah:

a) Tidak cocok untuk data besar

b) Dibandingkan SOAP, REST tidak meliputi semua jenis standar web service seperti keamanan, transaksi dll.

c) REST tidak handal

\section{METODOLOGI PENELITIAN}

\subsection{Pengumpulan Data}

Pengumpukan data yang digunakan dalam penelitian ini dilakukan dengan beberapa cara yaitu sebagai berikut [10]:

a) Studi Pustaka

Studi pustaka berisi kegiatan mempelajari literatur-literatur yang berhubungan dengan topik penelitian yaitu mengenai Sistem Informasi Manajemen PKL dan RESTFul Webservice. 
Literatur diperoleh dari berbagai sumber antara lain dari jurnal ilmiah, laporan hasil penelitian, majalah dan buku

b) Wawancara

Wawancara dilakukan dengan cara tanya jawab kepada orang-orang yang memiliki kapasitas informasi dan tanggung jawab yang dibutuhkan dalam penelitian ini diantaranya adalah kepala prodi, administrasi prodi, mahasiswa dan dosen pembimbing PKL.

c) Pengambilan Data

Pengambilan data berupa berbagai formulir hardcopy maupun softcopy pada prodi Sistem Informasi guna proses analisis, perancangan, implementasi dan pengujian aplikasi yang akan dibangun.

\subsection{Kebutuhan Sistem}

Kebutuhan sistem yang diperlukan dalam penelitian ini dapat dikelompokkan menjadi 3 yaitu kebutuhan data, hardware dan software. Adapaun data yang dibutuhkan dalam penelitian ini adalah sebagai berikut:
a) Data Dosen
b) Data Mahasiswa
c) Data Program Studi
d) Data Login
e) Data Pendaftaran PKL
f) Data Peserta PKL
g) Data Nilai PKL

Kebutuhan hardware dan software adalah sebagai berikut:

a) Komputer Server

Komputer server digunakan untuk menjaalankan aplikasi SIM PKL. Software yang diperlukan dalam komputer sever adalah Apache web server, MySql database dan PHP.

b) Web service

Web service digunakan untuk komunikasi (transfer data) dari server aplikasi SIM PKL dan server pusat data dasar universitas.

c) Komputer Client

Komputer client digunakan untuk mengakses aplikasi SIM PKL.

d) Jaringan Internet

Jaringan internet digunakan oleh komputer server dan client

\subsection{Desain Proses Bisnis}

Penelitian ini mengambil studi kasus pada program studi Sistem Informasi Fakultas Teknik Universitas Nusantara PGRI Kediri. Proses pelaksanaan Praktek Kerja Lapangan terlihat dalam Gambar 1.

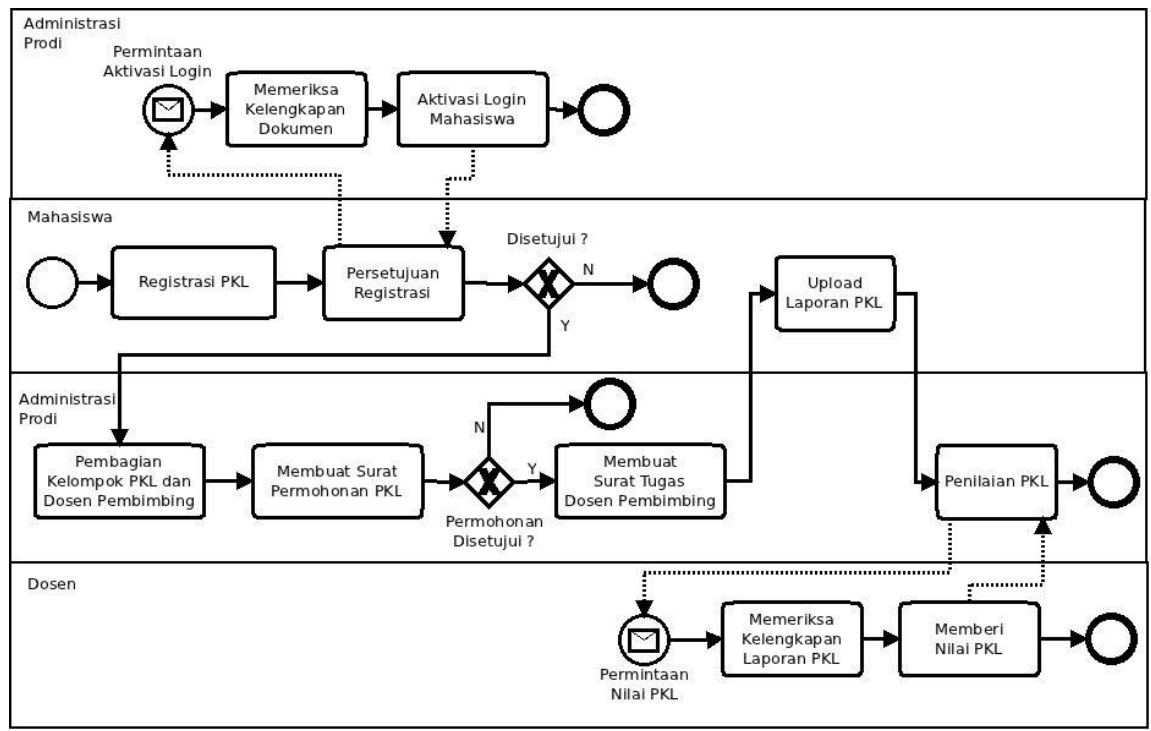

Gambar 1. Proses Bisnis Pelaksanaan PKL 
Mahasiswa melakukan registrasi PKL di prodi Sistem Informasi dengan menyerahkan kelengkapan dokumen yang disyaratkan. Admin Prodi selanjutnya akan memeriksa kelengkapan dokumen dan verifikasi data. Jika data sesuai maka admin prodi akan mengaktifkan login mahasiswa guna mengakses aplikasi SIM PKL. Selanjutnya admin prodi akan melakukan input data kelompok PKL dan 1 dosen pembimbing PKL. Surat permohonan PKL selanjutnya dapat di cetak oleh admin prodi untuk disampaikan kepata instansi tempat PKL. Jika surat permohonan tersebut disetujui, selanjutnya admin prodi akan membuat surat tugas dosen pembimbing PKL Setelah proses pelaksanaan PKL selesai dilakukan, selanjutnya kelompok PKL mahasiswa membuat laporan PKL untuk diupload ke dalam aplikasi SIM PKL. Setelah upload selesai, dosen pembimbing dapat memberikan nilai PKL.

\subsection{Desain Arsitektur Sistem}

Desain arsitektur PKL dapat digambarkan dalam Gambar 2. Pada Gambar 2 terdapat dua server yaitu Server Siakad dan Server PKL. Masing-masing server menggunakan webserver apache. Server Utama menggunakan sistem operasi Linux Debian, sedangkan server PKL menggunakan sistem operasi Linux Ubuntu. Pada server Siakad akan dibangun web service untuk melayani permintaan data mahasiswa dan progam studi. Web service tersebut akan terhubung dengan database sistem informasi akademik. Web service dibangun dengan menggunakan bahasa pemrograman PHP. Output dari web service tersebut berupa string JSON (Javascript Object Notation). Sedangkan pada server PKL dibangun Aplikasi Sistem Informasi Praktek Kerja Lapangan yang dibangun menggunakan bahasa pemrograman PHP. Pengguna dapat menggunakan layanan PKL dengan mengakses server PKL melalui jaringan komputer intranet maupun internet.

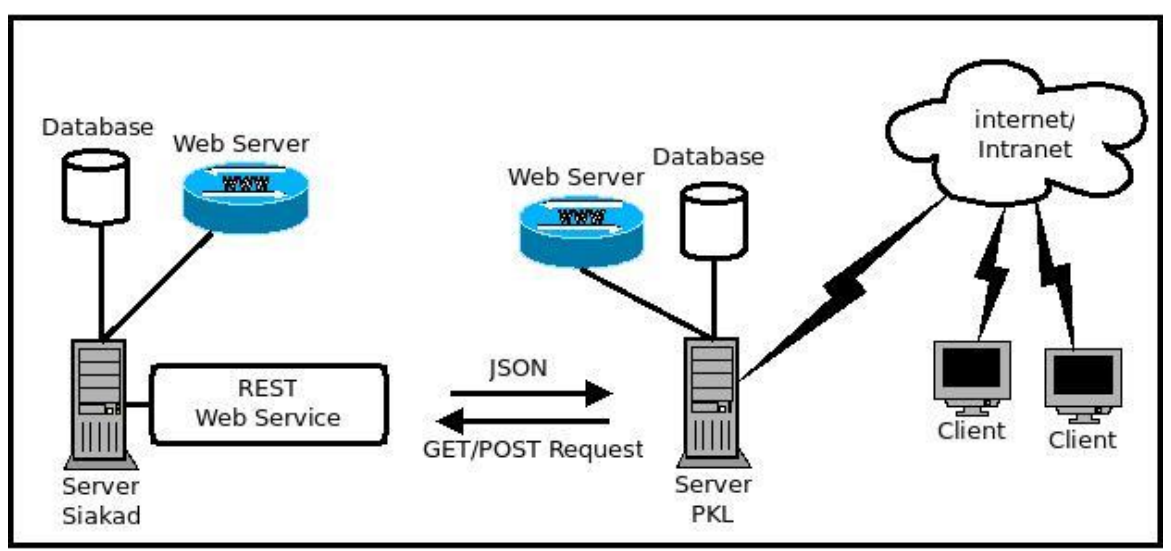

Gambar 2. Desain Arsitektur Sistem

\subsection{Desain Database}

Aplikasi PKL menggunakan 3 tabel database utama yaitu tabel kelompok, kelompok_detil dan srt_permohonan. Relasi antar tabel tersebut terlihat dalam Gambar 3.

\begin{tabular}{|c|c|c|}
\hline v o penelitian_pkl kelompok_detil & V o penelitian_pk kelompok & v o penelitian_pkl srt_permohonan \\
\hline iid : int(11) & id : $\operatorname{varchar}(20)$ & gid : int(11) \\
\hline kelompok_id : varchar(20) & q kode : varchar(20) & akelompok_id : varchar(20) \\
\hline 8ws_mhs_npm : varchar(20) & (anama : varchar(50) & enomor : varchar(50) \\
\hline \# is_koordinator : tinyint(1) & जtgl_mulai : date & qtanggal : date \\
\hline \#nilai_lapangan : float(5,2) & Gtgl_selesai : date & perihal : varchar(100) \\
\hline \# nilai_laporan : float(5,2) & lokasi : varchar(100) & Gepada_nama : varchar(200) \\
\hline \#nilai_ujian : float(5,2) & (aws_dosen_nip : varchar(20) & Gepada_alamat : varchar(200) \\
\hline \#nilai_angka : double(5,2) & (aws_prodi_id : varchar(20) & 自kode_mk: varchar(20) \\
\hline Gnilai_huruf : char(3) & - keterangan : text & Glembaga_nama : varchar(100) \\
\hline 自crt : varchar(20) & (act : varchar(20) & (apejabat_jabatan : varchar(100) \\
\hline ₫ort_date : timestamp & ⿴囗十 $\mathrm{cr}$ date : timestamp & _pejabat_nama : varchar(100) \\
\hline 目upd : varchar(20) & Gupd : varchar(20) & (apejabat_nip : varchar(100) \\
\hline ⿴囗⿴囗丨) upd_date : timestamp & Gupd_date : timestamp & ๑status : enum('dimohon','diterima','ditolak') \\
\hline & & 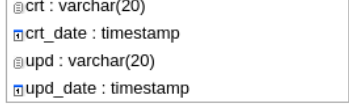 \\
\hline
\end{tabular}

Gambar 3. Relasi Tabel Database 


\section{HASIL PENELITIAN DAN PEMBAHASAN}

\subsection{Web Service}

Web Service digunakan untuk mengintegrasikan data mahasiswa dan program studiyang ada dalam database di server Siakad dan server PKL. Proses integrasi data mahasiswa dan program studi adalah sebagai berikut: aplikasi PKL akan melakukan request ke alamat web service. Selanjutnya web service akan memproses request dengan melakukan query kedalam database di server Siakad dan mengembalikan hasilnya dalam format JSON. Aplikasi PKL selanjutnya mengambil data kembalian tersebut untuk diproses dan ditampilkan dalam format HTML sesuai dengan kebutuhan. Kode program untuk mengirimkan request dan mengambil hasilnya terlihat dalam Gambar 4 dan Gambar 5.

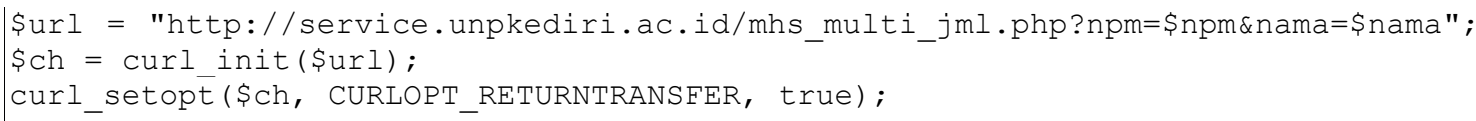

\section{Gambar 4. Kode Program Request Data Mahasiswa}

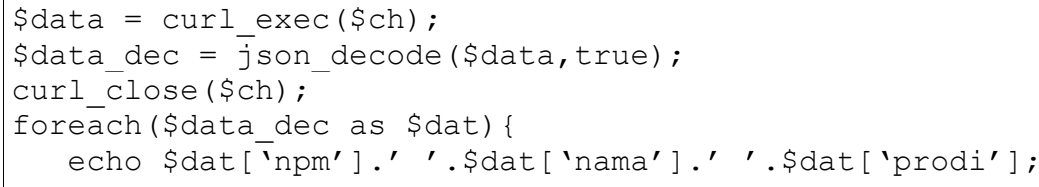

\section{Gambar 5. Kode Program Pengolahan Hasil Request Web Service}

Sedangkan kode program web service untuk melayani request data mahasiswa dan program studi terlihat dalam Gambar 6 dan Gambar 7.

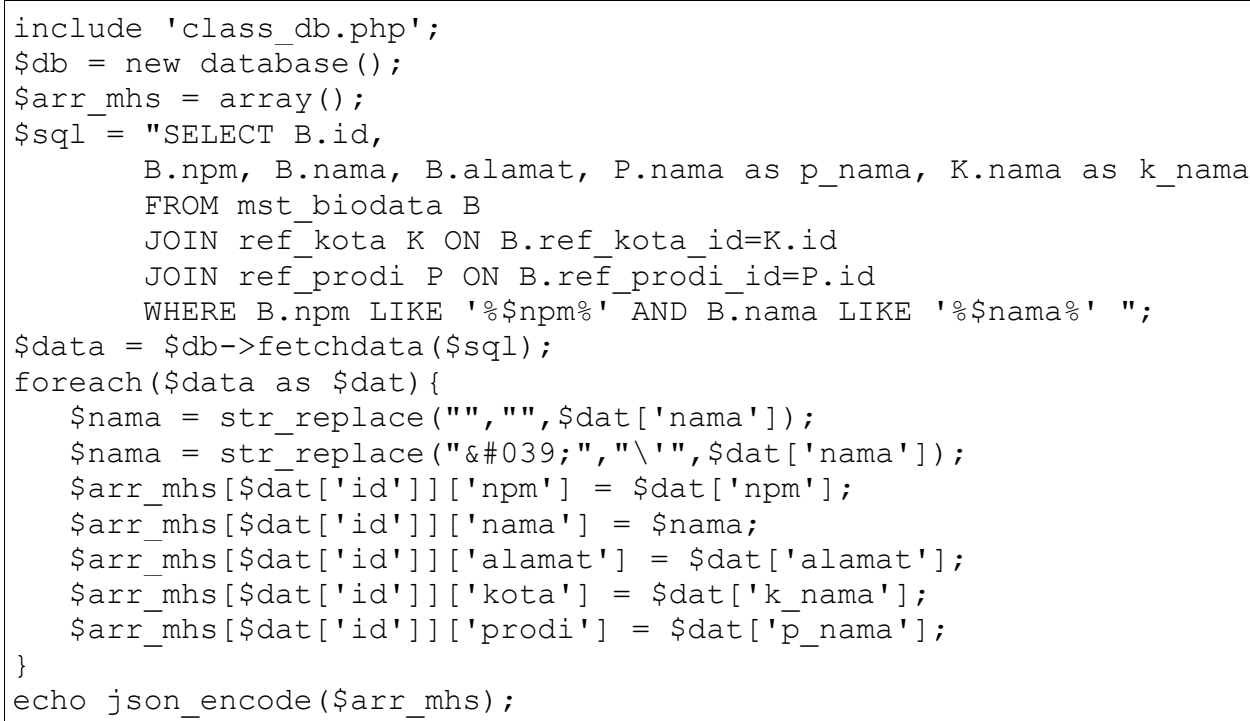

\section{Gambar 6. Kode Program Web Service Data Mahasiswa}

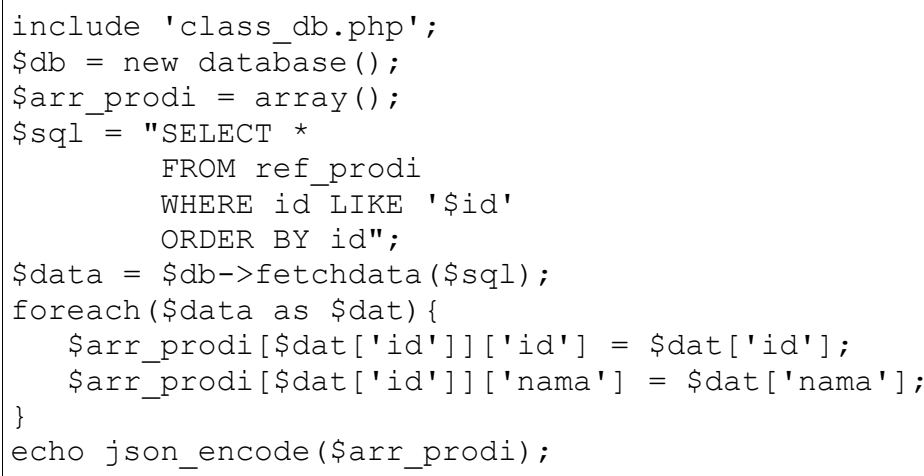

Gambar 7. Kode Program Web Service Data Program Studi 


\subsection{Manajemen Pengguna}

Aplikasi PKL dilengkapi dengan manajemen pengguna. Pengguna dikelompokkan menjadi beberapa group yaitu group dosen dan mahasiswa. Setiap group memiliki hak akses yang berbeda. Username pengguna menggunakan NPM mahasiswa atau NIP dosen. Group mahasiwwa memiliki hak akses untuk melihat daftar anggota kelompok masing-masing, mengunggah laporan PKL dan melihat nilai PKL. Sedangkan group dosen memiliki hak akses untuk melihat daftar kelompok yang dibimbing, mengunduh laporan PKL dan memberikan nilai PKL. Proses input kelompok, anggota kelompok, waktu dan tempat PKL serta dosen pembimbing dilakukan oleh admin aplikasi.

\subsection{Kelompok PKL}

Input kelompok PKL dilakukan oleh admin. Form input kelompok terlihat dalam Gambar 8. Pada form tambah kelompok, pengguna diminta untuk memasukkan data kode dan nama kelompok, tanggal dan lokasi PKL, program studi, dosen pembimbing serta anggota kelompok PKL. Data program studi, dosen pembimbing dan mahasiswa merupakan data hasil request web service yang terintegrasi dengan data sistem informasi akademik.

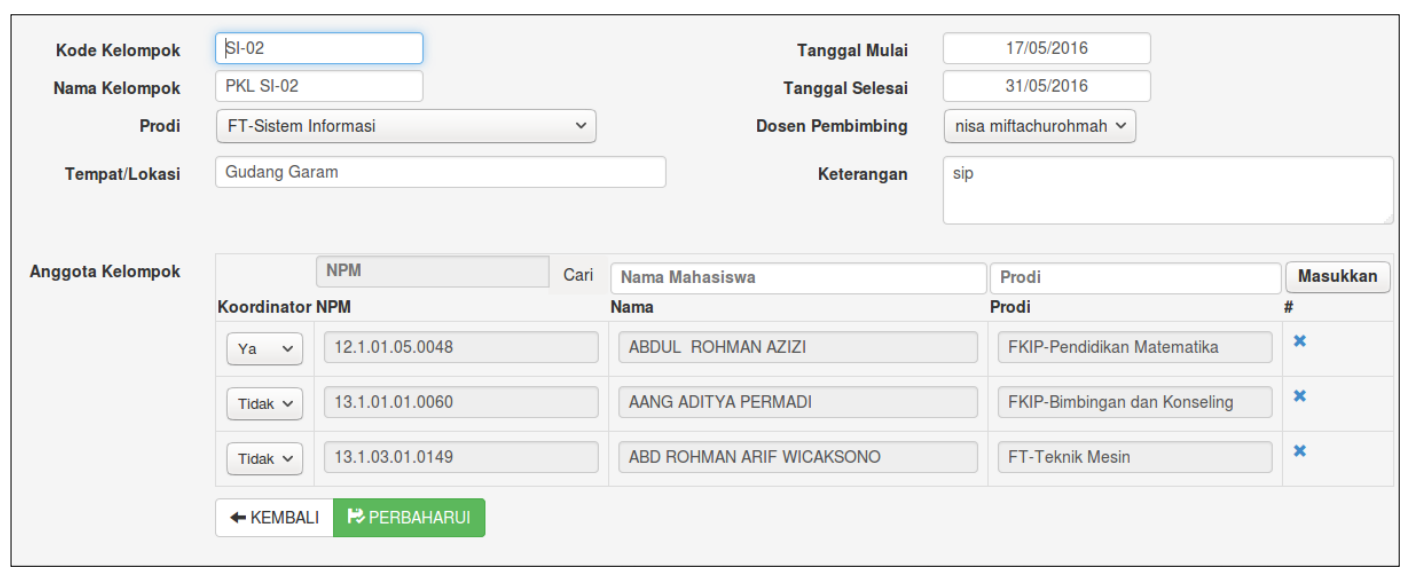

Gambar 8. Form Kelompok PKL

\subsection{Surat Permohonan}

Untuk meminta persetujuan PKL dari instansi tujuan, maka admin akan membuat Surat Permohonan PKL. Data input dalam surat permohonan PKL menyesuaiakn sesuai dengan print out yang selama ini digunakan. Data input tesebut adalah kelompok, nomor surat, tanggal surat, perihal, peruhal dan tujuan surat serta kode mata kuliah. Data input identitas pengirim surat yaitu nama lembaga, jabatan, nama pejabat dan NIP pejabat. Status surat terdiri dari tiga status yaitu dimohon, diterima dan ditolak. Admin akan mengubah status surat menjadi diterima atau ditolak sesuai dengan surat balasan dari instansi yang dituju.

\subsection{Upload Download Laporan PKL}

Setelah PKL selesai dilaksanakan selanjutnya mahasiswa membuat laporan PKL. Selanjutnya mahasiswa mengunggah laporan PKL tersebut kedalam aplikasi PKL dalam format pdf. Dosen pembimbing selanjutnya dapat mengunduh laporan PKL tersebut yang akan direview untuk memberikan nilai akhir. Menu unggah dan unduh laporan PKL terdapat dalam halaman kelompok PKL.

\subsection{Penilaian PKL}

Tahapan terakhir PKL yaitu penilaian hasil PKL yang dilakukan oleh dosen pembimbing. Terdapat tiga jenis nilai yaitu nilai instansi, nilai laporan dan nilai ujian. Nilai instansi diberikan oleh instansi tempat pelaksanaan PKL. Sedangkan nilai laporan dan ujian diberikan oleh dosen pembimbing. Nilai instansi, laporan dan ujian diberikan dalam bentuk angka skala $0-100$. Nilai angka akhir dihitung dari rata-rata ketiga nilai tersebut yang selanjutnya dikonversi menjadi nilai huruf. Form penilaian terlihat dalam Gambar 9. 


\begin{tabular}{|c|c|c|c|c|c|}
\hline \multicolumn{2}{|c|}{ Koordinator NPM } & Nama & Prodi & \multicolumn{2}{|l|}{ Nilai Angka } \\
\hline Ya $\sim$ & 12.1.01.05.0036 & A. PUTRI PAULA ASTIARI & FKIP-Pendidikan Matematika & 83 & $x$ \\
\hline Tidak $\sim$ & 13.1.02.02.0222 & Al & FE-Manajemen & 78 & $\mathbf{x}$ \\
\hline Tidak $\sim$ & 14.1.03.03.0098 & A FIKRY AZIZAN & FT-Sistem Informasi & 85 & $\mathbf{x}$ \\
\hline$\leftarrow$ KEMBAL & P. PERBAHARUI & & & & \\
\hline
\end{tabular}

Gambar 9. Form Penilaian PKL

\section{KESIMPULAN}

Pada penelitian ini dihasilkan kesimpulan sebagai berikut:

a) Telah dihasilkan aplikasi Sistem Informasi Praktek Kerja Lapangan yang telah terintegrasi dengan Sistem Informasi Akademik.

b) Data yang terintegrasi antara Sismtem Inormasi PKL dan Sistem Informasi Akademik adalah data mahasiswa, dosen dan program studi.

c) Sistem Informasi PKL dapat digunakan untuk mendukung sistem pelaporan dan monitoring pelaksanaan PKL.

\section{UCAPAN TERIMAKASIH}

Penulis mengucapkan terima kasih kepada Bapak Budi Hartono dan Andri Wiratmono selaku Kepala dan Staf Biro Sistem Informasi Universitas Nusantara PGRI Kediri yang telah menyediakan akses data serta infrastruktur yang diperlukan dalam penelitian ini.

\section{DAFTAR PUSTAKA}

[1] Universitas Nusantara PGRI Kediri, 2015, Panduan Pelaksanaan Kurikulum 2015

[2] Muhammad Arifin, 2014, Analisa dan Perancangan Sistem Informasi Praktek Kerja Lapangan Pada Instansi/Perusahaan, Jurnal SIMETRIS, Vol 5 No 1, ISSN: 2252-4983

[3] Ryan Adiwinata, Eko Adi Sarwoko, Indriyati, 2011, Sistem Informasi Tugas Akhir dan Praktek Kerja Lapangan Berbasis Web Menggunakan Metode Unified Process, Jurnal Masyarakat Informatika Volume 2 Nomor 3, ISSN 2086-4930

[4] Fendhika Chandra.K, Adriyanto J. Gundo, Ramos Somya, 2013, Perancangan dan Implementasi Sistem Informasi Manajemen Praktek Kerja Lapangan Berbasis Web Menggunakan YUI Library (Studi Kasus: PT. PLN (Persero) P3B Jawa Bali APP Salatiga), Jurnal Teknologi Informasi - Aiti, Vol.10: 101-200

[5] Budi Santosa, Dessyanto Boedi Prasetyo ,Yunita Pungki, 2011, Integrasi Toko Online Menggunakan Teknologi Web Service, TELEMATIKA Vol. 8, No. 1, JULI 2011 : 33 - 42

[6] Rokhmat Hidayat, Ahmad Ashari, 2013, Penerapan Teknologi Web Service Untuk Integrasi layanan Puskesmas dan Rumah Sakit, Berkala MIPA, (23)1, Januari 2013

[7] Edhy Sutanta, Khabib Mustofa2, 2012, Kebutuhan Web Services Untuk Sinkronisasi Data Antar Sistem Informasi Dalam E-Gov di Pemkab Bantul Yogyakarta, JURTIK - STMIK BANDUNG (edisi Mei 2012)

[8] Pautasso, C., 2008, REST vs SOAP Making the Right Architectural Decision, SOA Symposium, Amsterdam.

[9] Vibha Kumari, 2015, Web Services Protocol: SOAP vs REST, International Journal of Advanced Research in Computer Engineering \& Technology (IJARCET) Volume 4 Issue 5.

[10] Roger S. Pressman, Ph.D, 2010, Software Engineering: A Practitioner's Approach, seven edition, Mc Graw Hil Higer Education. 